\title{
PEMANFAATAN TUMBUHAN OBAT OLEH MASYARAKAT DI SEKITAR HUTAN ADAT TAWANG PANYAI DI DESA TAPANG SEMADAK KECAMATAN SEKADAU HILIR KABUPATEN SEKADAU
}

\author{
(Utilization of Medicinal Plants by People Around the Tawang Panyai Indigenous Forest in \\ Tapang Semadak Village Sekadau Hilir District Sekadau Regency)
}

\author{
Desi Sulatri, Emi Rosalinda, Yeni Mariani \\ Fakultas Kehutanan Universitas Tanjungpura Pontianak. J1. Daya Nasional Pontianak 78124 \\ Email: desisulastri0408@gmail.com
}

\begin{abstract}
The abundant biodiversity in the Tawang Panyai Indigenous Forest area has a variety of tree species including timber producers, fruit-producing trees, rattan, bamboo and medicinal plants that are used by communities around indigenous forests. The aims of this study were to documented the use and knowledge of medicinal plants by people around the Tawang Panyai Indigenous Forest in Tapang Semadak Village, Sekadau Hilir District, Sekadau District. The method used in this study was survey method with data collection techniques, namely Purposive sampling conducted semi-structured interview techniques using questionnaires and field observations. The results of the study in Tapang Semadak Village, Sekadau Hilir Subdistrict, Sekadau District, towards 248 respondents obtained by respondents who used medicinal plants were women. Most of the respondents worked as farmers due their education level are still very low, so the majority chose to garden and cultivate. Adults and elderly respondent are more have knowledge of medicinal plants than others. The majority of the religious community is Catholic with Dayak tribe De'sa. The results of the study in the field found 52 types of medicinal plants grouped into 33 families. The plant of family that is widely used is zingiberaceae, based on the most widely used habitus level which is 17 species (32.08\%), based on the form of the herb that is widely used is a single herb which is 49 species (92\%), based on plant the most widely used drug is leaves, which are 31 species (58.49), based on the method of medicinal plants the most widely used is boiled, namely 27 species (49.06\%), based on the method of use that is widely used is by drinking that is 29 species (54.72\%), based on the type of disease that is widely used is internal disease, which is 32 species (62.26), based on plants that are found mostly in the traditional forest of Tawang Panyai and home gardens.
\end{abstract}

Keywords: Medicinal Plants, Tawang Panyai Customary Forest, Utilization

\section{PENDAHULUAN}

Kalimantan Barat memiliki sumberdaya hutan yang cukup tinggi, dengan berbagai jenis tumbuhan obat. Tumbuhan obat tradisional di Indonesia bagi masyarakat di daerah pedesaan yang fasilitas kesehatannya masih sangat terbatas mempunyai peran yang sangat penting. Obat-obatan tradisional yang berasal dari tumbuhan disekitar pekarangan rumah maupun yang tumbuh liar disemak belukar dan hutan-hutan sudah dikenal lama dari nenek moyang dahulu. Tumbuhan obat masih digunakan masyarakat dikarenakan bahan-bahan yang mudah didapat selain itu relatif memiliki efek samping yang kecil serta murah dibandingkan dengan obat-obatan sintesis sehingga masyarakat masih menggunakan tumbuhan obat tradisional 
dalam menyembuhkan berbagai macam penyakit (Kumalasari, 2006).

Pemanfaatan tumbuhan obat diwariskan secara turun-temurun berdasarkan pengetahuan masyarakat sekitar kawasan hutan yang memanfaatkan tumbuhan obat sebagai bahan baku obatobatan (Hidayat dan Hardiansyah, 2012). Pemanfaatan tumbuhan obat dari hasil studi etnobotani dibeberapa Kabupaten di Kalimantan Barat menunjukkan bahwa jenis tumbuhan yang digunakan sangat beragam, mencakup lapisan tumbuhan liana, perdu dan berbunga jenis pohon (Leonardo et al. 2013). Sebagian besar masyarakat Kalimantan Barat yang sampai saat ini masih mempertahankan adat dan tradisi dalam penggunaan sumberdaya alam berupa tumbuhan obat salah satunya adalah masyarakat di sekitar kawasan Hutan Adat Tawang Panyai Desa Tapang Semadak Kecamatan Sekadau Hilir Kabupaten Sekadau.

Berdasarkan Keputusan Bupati No 180/392/HK-A/2016 tanggal 28 Desember 2016 telah menetapkan Rimak Adat Tawang Panyai sebagai Hutan Adat di wilayah Adat Tapang Sambas-Tapang Kemanyau dalam wilayah administrasi Desa Tapang Semadak, Kecamatan Sekadau Hilir Kabupaten Sekadau Provinsi Kalimantan Barat dengan luas 土40,5 Ha. Lahan Rimak Adat Tawang Panyai merupakan lahan hak/pengelolaan masyarakat Adat Tapang Sambas-Tapang Kemanyau.

Jenis-jenis tumbuhan obat yang terdapat di Kawasan Hutan Adat Tawang Panyai belum mendapatkan perhatian sehingga informasi mengenai jenis-jenis tumbuhan obat belum tersedia. Sebelum melakukan penyebarluasan pemanfaatan tumbuhan obat perlu dilakukan pengenalan terhadap berbagai jenis tumbuhan obat itu sendiri (Hamzari, 2008). Oleh karena itu, perlu adanya identifikasi jenis-jenis tumbuhan obat yang sering dimanfaatkan oleh masyarakat sekitar Hutan Adat Tawang Panyai Desa Tapang Semadak Kecamatan Sekadau Hilir Kabupaten Sekadau. Hal itu berfungsi memberikan informasi mengenai data tumbuhan-tumbuhan obat dan sarana untuk mengikutsertakan masyarakat didalam upaya pelestarian sumber daya alam khususnya sumber daya alam bukan kayu. Guna mengetahui pemanfaatan tumbuhan obat yang sering digunakan oleh masyarakat, maka dilakukan penelitian tentang pemanfaatan tumbuhan obat oleh masyarakat di sekitar Hutan Adat Tawang Panyai Desa Tapang Semadak Kecamatan Sekadau Hilir Kabupaten Sekadau.

\section{METODE PENELITIAN}

Penelitian ini dilaksanakan pada kawasan Hutan Adat Tawang Panyai di Desa Semadak Kecamatan Sekadau Hilir Kabupaten Sekadau dengan kurun waktu penelitian selama 1 bulan efektif di lapangan mulai 30 Juni - 30 Juli 2018. Alat dan bahan yang digunakan dalam penelitian ini adalah peta lokasi penelitian (Skala 1 : 80.000), GPS, Kuisioner (Daftar pertanyaan untuk responden terpilih), Tally sheet, Kamera untuk dokumentasi, Buku daftar tumbuhan obat Indonesia untuk identifikasi tumbuhan obat, Buku Kitab Tumbuhan obat. Metode yang digunakan dalam penelitian ini adalah 
metode Survey dengan teknik pengambilan data yaitu purposive sampling yang dilanjutkan dengan teknik wawancara semi struktur menggunakan kuisioner dan pengamatan di lapangan. Kriteria sampel sebagai sumber data atau sebagai informan adalah masyarakat yang tinggal di Desa Tapang Semadak lebih dari 5 tahun yang menguasai atau mengetahui tumbuhan obat.

Menurut Sarwono (2006) untuk menentukan besarnya responden dalam rencana penelitian dapat dihitung dengan menggunakan rumus Slovin sebagai berikut:

$n=\frac{N}{1+N e^{2}}$

Keterangan:

$\mathrm{n}=$ Jumlah sampel responden

$\mathrm{N}=$ Jumlah populasi responden

$\mathrm{e}=$ Batas toleransi kesalahan (persen kesalahan)

Jumlah populasi yang ada di Desa Tapang Semadak keseluruhan berjumlah $651 \mathrm{KK}$, yang terdiri atas 5 dusun yang meliputi Dusun Tapang Kemanyau, Dusun Tapang Sambas, Dusun Tapang Semadak, Dusun Janang Sebatu dan Dusun Perupuk Mentah. Jumlah sampel responden yang digunakan adalah 248.

Pengumpulan data di lapangan berupa pedoman wawancara, yaitu dengan menggunakan kuesioner yang telah dipersiapkan sebelumnya. Isi daftar pertanyaan untuk responden terpilih meliputi karakteristik responden seperti (jenis kelamin, umur, agama, pendidikan, status perkawinan, pekerjaan dan suku) serta jenis-jenis tumbuhan yang dimanfaatkan sebagai obat, bagian tumbuhan yang digunakan, bagaimana cara menggunakannya, bagaimana cara memperolehnya, darimana sumber informasi penggunaannya, efek samping penggunaan obat dan jumlah responden yang menggunakan untuk setiap tumbuhan obat. Pengamatan (observasi) dilakukan dengan cara sambil berjalan (tanpa plot) bersama-sama responden yang mengetahui dengan pasti tumbuhan tersebut dan mengambil dokumentasi untuk mendapatkan nama ilmiah dilakukan identifikasi dengan cek silang berdasarkan literatur dan buku tentang tumbuhan obat yang ada meliputi nama lokal, nama latin, famili dan habitus.

Data yang didapatkan kemudian dipersentasikan menggunakan rumus sebagai berikut :

1. Persentase pengetahuan responden berdasarkan karakteristik responden yang mengatahui tumbuhan obat

Karakteristik responden

$=\frac{\text { Jumlah tumbuhan }}{\text { Jumlah responden }} \times 100 \%$

2. Persentase pemanfaatan tumbuhan obat berdasarkan penyakit

Jenis tumbuhan

$=\frac{\text { Jenis Penyakit yang bisa diobati }}{\text { Jumlah penyakit yang bisa diobati }} \times 100 \%$

3. Persentase organ tumbuhan yang digunakan

Organ tumbuhan

$=\frac{\text { Organ yang digunakan }}{\text { Jumlah organ yang bisa digunakan }} \times 100 \%$

4. Kegunaan suatu jenis (use value) untuk tumbuhan obat dilakukan dengan menggunakan rumus Philips dan Gentry (1993) (Hoffman dan Gallaher, 2007) :

$$
\mathrm{UVis}=\frac{\sum U i s}{n i s}
$$

Dimana: 
UVis : Nilai kegunaan (manfaat) suatu jenis tertentu (i) yang disampaikan oleh informan (s)

$\sum$ Uis : Jumlah seluruh pengguna jenis (i) yang dijelaskan setiap kali bertanya nis : Jumlah total informan yang diwawancarai untuk nilai guna jenis

Data hasil wawancara kemudian dianalisis yang meliputi data karakteristik responden (tingkat pengetahuan berdasarkan jenis kelamin, umur, Agama, pekerjaan, pendidikan, dan suku), pengetahuan masyarakat dari banyaknya tumbuhan obat yang dimanfaatkan (1-5, 56 dan $>10$ jenis tumbuhan) serta pemanfaatan tumbuhan obat. Berdasarkan hal tersebut diperoleh hasil kajian etnobotani tumbuhan obat yang meliputi jenis tumbuhan, famili, bagian yang digunakan, cara pemanfaatan dan pengobatan serta jenis penyakit yang dapat diobati kemudian dianalisis sehingga diperoleh hasil gambaran atau secara sistematik, akurat.

\section{HASIL DAN PEMBAHASAN}

Responden didalam penelitian ini adalah masyarakat Desa Tapang Semadak Kecamatan Sekadau Hilir Kabupaten Sekadau yang memanfaatkan tumbuhan obat. Jumlah responden yang diambil sebanyak 248 responden. Data yang diperoleh dalam penelitian ini berdasarkan wawancara terhadap responden Tingkat pemanfaatan responden terhadap tumbuhan obat di kelompokkan berdasarkan jumlah informasi tumbuhan obat yang diberikan (1-5, 6-10, dan lebih dari 10 tumbuhan obat), berdasarkan informasi pribadi seperti jenis kelamin, umur, agama, pekerjaan, pendidikan dan suku.

\section{Tingkat Pemanfaatan Responden Berdasarkan Jenis Kelamin}

Tingkat pengetahuan responden terhadap tumbuhan obat berdasarkan jenis kelamin dapat dilihat pada Gambar 1.

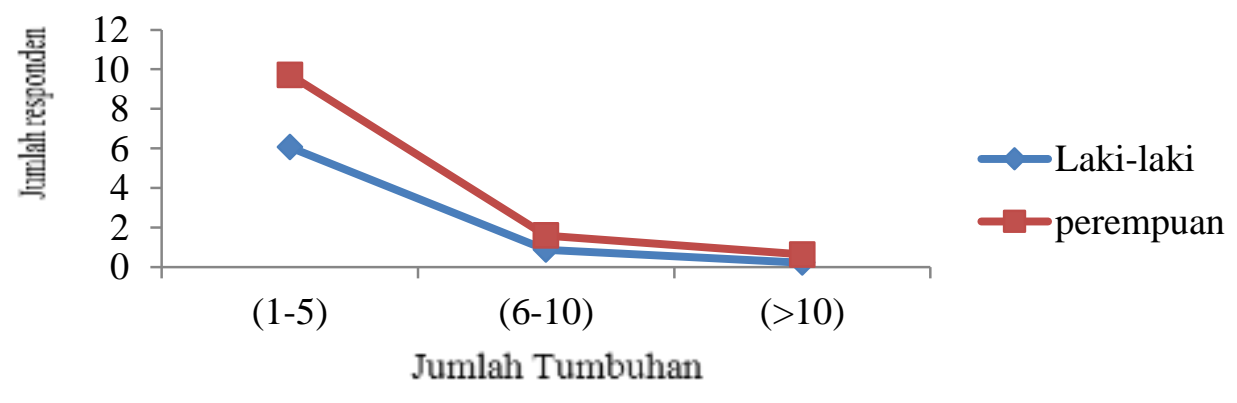

Gambar 1. Tingkat Pemanfaatan Responden Berdasarkan Jenis Kelamin (Respondents Utilization Level Based on Gender)

Responden yang terbanyak mengetahui pemanfaatan tumbuhan obat merupakan responden dengan jenis kelamin perempuan. Pengetahuan perempuan berdasarkan informasi jumlah tumbuhan yang diberikan yaitu
1-5 jenis tumbuhan sebanyak 123

$(9,72 \%)$ responden, 6-10 jenis tumbuhan sebanyak $20 \quad(1,59 \%)$ responden dan lebih dari 10 jenis tumbuhan sebanyak $8 \quad(0,63 \%)$ responden. Menurut Voeks (2007) 
perempuan lebih banyak tahu jumlah spesies tumbuhan obat daripada lakilaki, karena wanita mengelola dan bertanggung jawab untuk perawatan kesehatan keluarganya sedangkan lakilaki banyak menghabiskan waktu diluar rumah atau bekerja.

\section{Tingkat Pemanfaatan Responden Berdasarkan Umur}

Tingkat pengetahuan responden yang menggunakan tumbuhan obat berdasarkan umur dapat dilihat pada Gambar 2.

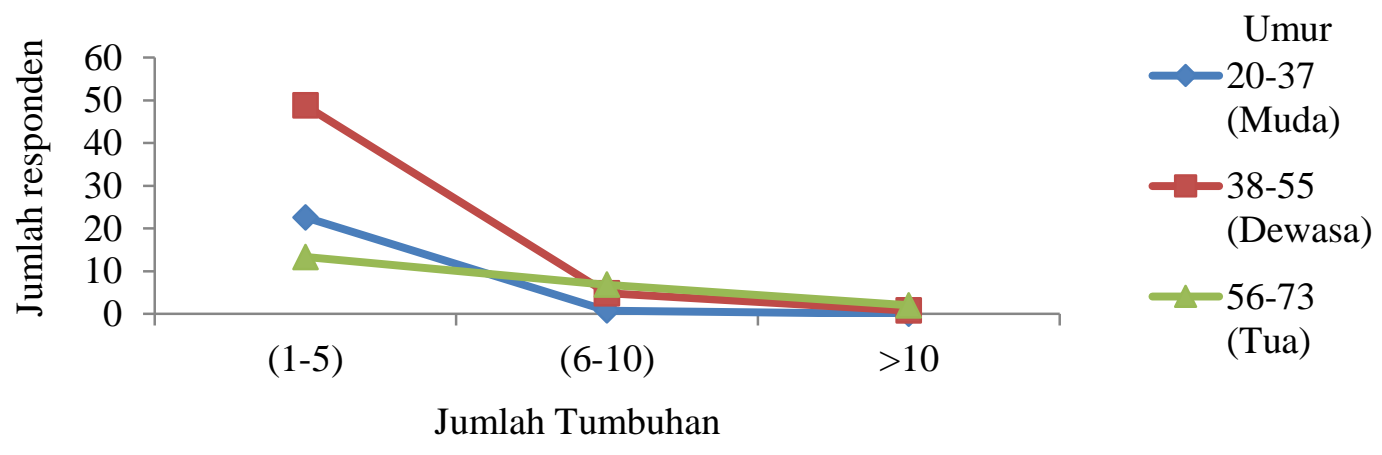

Gambar 2. Tingkat Pemanfaatan Responden Berdasarkan Umur (Respondents Utilization Level Based on Age)

Hasil penelitian menunjukkan bahwa banyaknya responden yang menggunakan dan mengetahui jenis tumbuhan obat adalah pada kategori tingkat umur dewasa dan tua yaitu dengan umur 30 ke atas. Hasil penelitian Due et al .(2013) juga menunjukkan bahwa masyarakat suku Dayak Pesaguan yang mengetahui pemanfaatan tumbuhan obat adalah informan yang tergolong dalam umur dewasa dan lansia, hal ini dikarenakan semakin bertambahnya usia serta anggota keluarga maka pengetahuan yang diperoleh akan semakin bertambah.

Tingkat Pemanfaatan Responden Berdasarkan Agama

Tingkat pengetahuan responden yang menggunakan tumbuhan obat berdasarkan agama dapat dilihat pada Gambar 3.

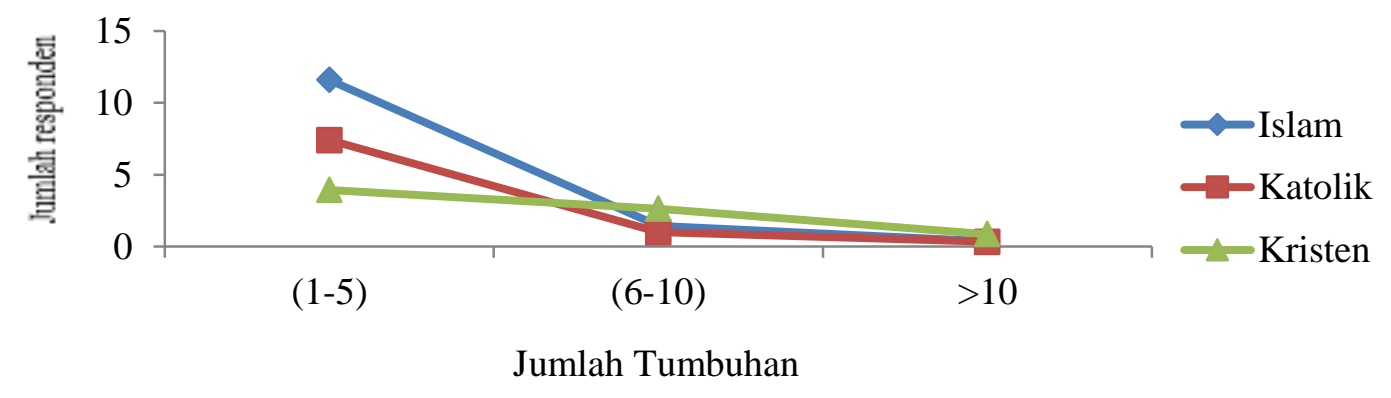

Gambar 3. Tingkat Pemanfaatan Responden Berdasarkan Agama (Respondents Utilization Level Based on Religion)

Responden yang mengetahui dan menggunakan tumbuhan obat tertinggi yaitu responden yang beragama Islam yang didasarkan pada jumlah responden 
yang ditemui dan jumlah masyarakat yang beragama Islam di desa tersebut. Jumlah responden yang beragama Katolik dalam mengetahui tanaman obat juga tinggi dikarenakan masyarakat di Desa Tapang Semadak Kecamatan Sekadau Hilir Kabupaten Sekadau merupakan masyarakat yang mayoritas penduduknya beragama katolik. Tumbuhan obat yang sering digunakan oleh masyarakat yang beragama Katolik, Islam dan Protestan di Desa Tapang Semadak hampir sama, karena mereka pada umumnya masih memiliki hubungan kekerabatan.

\section{Tingkat Pemanfaatan Responden Berdasarkan Pekerjaaan}

Tingkat pengetahuan responden berdasarkan pekerjaan dapat dilihat pada Gambar 4.

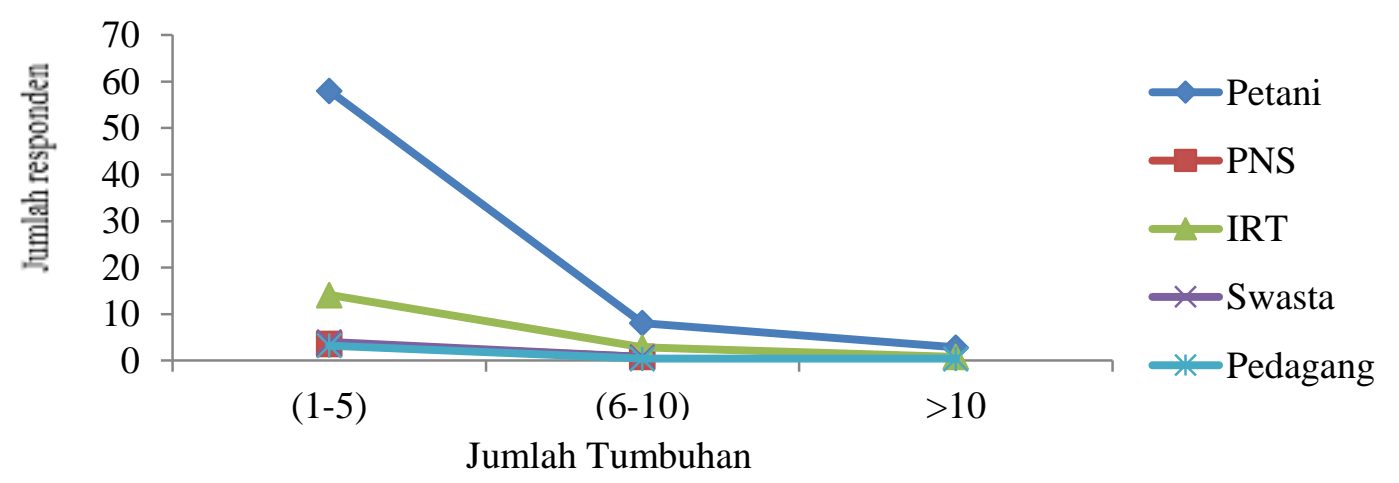

Gambar 4. Tingkat Pemanfaatan Responden Berdasarkan Pekerjaan (Respondents Utilization Levels Based on Work)

Berdasarkan tingkat pekerjaan, responden yang mengetahui dan menggunakan tumbuhan obat terbanyak yaitu responden yang bekerja sebagai petani, seperti halnya data yang diperoleh dari kantor kepala desa bahwa 1.255 orang atau 84,71 \% penduduk Desa Tapang Semadak adalah bermata pencaharian sebagai petani. Petani dianggap lebih banyak mengetahui tentang pemanfaatan tumbuhan karena mereka memiliki interaksi yang tinggi dengan hutan (Due et al. 2013).

\section{Tingkat Pemanfaatan Responden} Berdasarkan Pendidikan

Tingkat pengetahuan responden berdasarkan pendidikan dapat dilihat pada Gambar 5. 


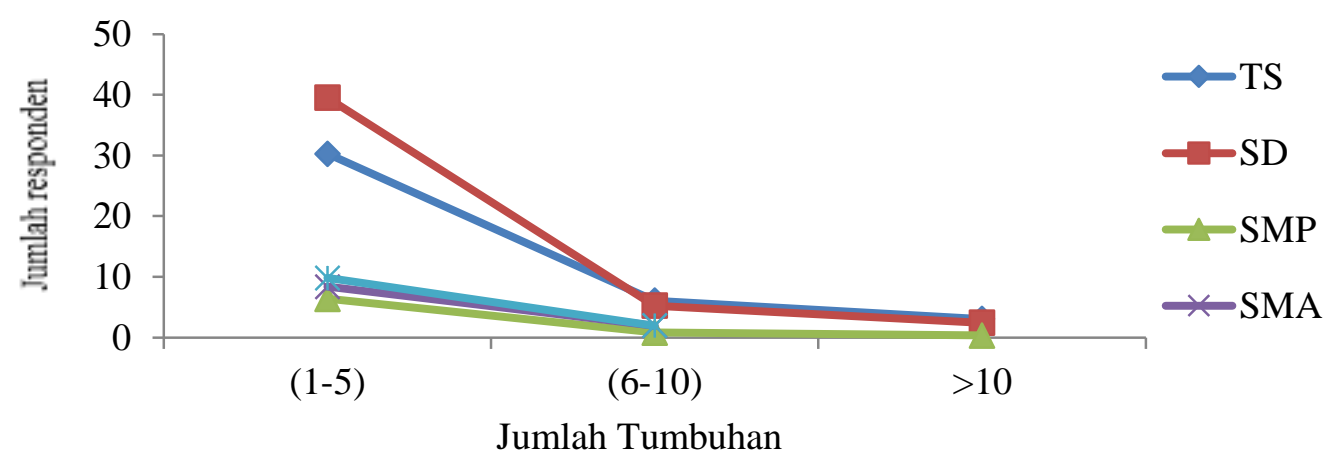

Gambar 5. Tingkat Pemanfaatan Responden Berdasarkan Pendidikan (Respondents Utilization Level Based on Education)

Berdasarkan hasil wawancara diperoleh bahwa pendidikan masyarakat yang menjadi responden memiliki tingkat pendidikan yang masih rendah yaitu Sekolah Dasar (SD). Rendahnya tingkat pendidikan masyarakat di Desa Tapang Semadak disebabkan oleh meningkatnya tuntutan hidup pada masa lalu, sehingga banyak masyarakat yang memilih bekerja untuk membantu memenuhi kebutuhan ekonomi mereka dari pada sekolah. Tingkat pendidikan masyarakat Desa Tapang Semadak masih tergolong rendah namun masyarakat tradisional ini masih menjaga kelestarian tumbuhan yang ada didaerahnya termasuk tumbuhan obat yang dilihat dari masih banyaknya yang memanfaatkan tumbuhan obat.

Tingkat Pemanfaatan Responden Berdasarkan Suku

Tingkat pengetahuan responden berdasarkan suku dapat dilihat pada Gambar 6.

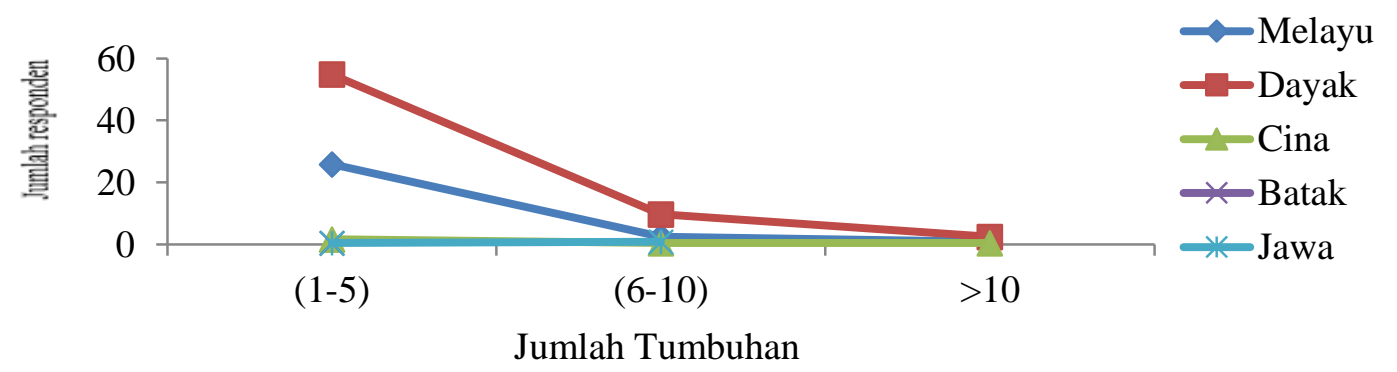

Gambar 6. Tingkat Pemanfaatan Responden Berdasarkan Suku (Respondents Utilization Level Based on Tribe)

Diketahui bahwa pengetahuan responden berdasarkan suku responden yang banyak mengetahui dan menggunakan tumbuhan obat adalah masyarakat suku dayak. Suku dayak sering disebut "Penduduk Asli" Pulau Kalimantan atau salah satu kelompok besar penduduk yang tersebar di wilayah administratif Provinsi Kalimantan Barat. Masyarakat suku dayak merupakan masyarakat yang terkenal dengan kekeluargaan, kepercayaan, adat istiadat dan kebudayaan. 
Berdasarkan hasil dari wawancara dengan masyarakat di Desa Tapang Semadak Kecamatan Sekadau Hilir Kabupaten Sekadau tercatat 52 jenis tumbuhan yang dimanfaatkan oleh masyarakat dan 33 famili. Informasi tumbuhan tersebut terdiri dari jenis, famili, habitus, manfaat, bagian yang digunakan, cara pengolahan, cara penggunaan dan banyaknya pengguna yang disajikan pada Tabel 1.

Tabel 1. Tumbuhan Obat yang Dimanfaatkan oleh Masyarakat di Desa Tapang Semadak Kecamatan Sekadau Hilir Kabupaten Sekadau (Medicinal Plants Used by Communities in Tapang Semadak Village Sekadau Hilir District Sekadau Regency)

\begin{tabular}{|c|c|c|c|c|c|c|c|c|}
\hline No & Nama Lokal & Nama Latin & Famili & Habitus & Manfaat & $\begin{array}{l}\text { Bagian } \\
\text { yang } \\
\text { digunakan }\end{array}$ & $\begin{array}{l}\text { Cara } \\
\text { pengolahan }\end{array}$ & $\begin{array}{l}\text { Cara } \\
\text { Penggunaan }\end{array}$ \\
\hline 1 & $\begin{array}{l}\text { Akar } \\
\text { emprekak }\end{array}$ & $\begin{array}{l}\text { Adenia marcophylla } \\
\text { (Blume) Kds }\end{array}$ & Passifloraceae & $\begin{array}{ll}\text { Liana } \\
\end{array}$ & Rematik & Akar & $\begin{array}{l}\text { Langsung } \\
\text { dipakai }\end{array}$ & Diminum \\
\hline 2 & Akar Rente & Dischidia acutifolia & Apocynaceae & Liana & Malaria & Daun & Direbus & Diminum \\
\hline 3 & Akar Ridu & Tinospora crispa $\mathrm{L}$. & Menispermaceae & Liana & Malaria & Akar & Direbus & Diminum \\
\hline 4 & $\begin{array}{l}\text { Bawang } \\
\text { lomak }\end{array}$ & $\begin{array}{l}\text { Eleutherine } \\
\text { americana Merr. }\end{array}$ & Liliaceae & Herba & Kolestrol & Umbi & Direbus & Diminum \\
\hline 5 & Belimbing & Averhoa bilimbi L. & Oxalidaceae & Pohon & Penurun darah & Daun & Diremas & Diminum \\
\hline 6 & Bungkang & $\begin{array}{l}\text { Syzigium } \\
\text { polyanthum (Wight). } \\
\text { Walp }\end{array}$ & Myrtaceae & Pohon & Gatal-gatal & Daun & Direbus & $\begin{array}{l}\text { Untuk } \\
\text { mandi }\end{array}$ \\
\hline 7 & Cekur & $\begin{array}{l}\text { Kaempferia galanga } \\
\text { L. }\end{array}$ & Zingiberaceae & Herba & Sakit perut & Rimpang & Ditumbuk & Ditempel \\
\hline 8 & Cekur antu & $\begin{array}{l}\text { Kaempferia } \\
\text { parviflora }\end{array}$ & Zingiberaceae & Herba & $\begin{array}{l}\text { Susah } \\
\text { pencernaan } \\
\text { anak }\end{array}$ & Daun & Diremas & Digosok \\
\hline 9 & Engkelinang & $\begin{array}{l}\text { Blechnum orientale } \\
\text { Burm. }\end{array}$ & Blechnaceae & Herba & Bisul & Daun & Ditumbuk & Ditempel \\
\hline 10 & Engkrebang & $\begin{array}{l}\text { Psychotria } \\
\text { viridiflora }\end{array}$ & Rubiceae & Perdu & Sakit perut & Daun & Direbus & Diminum \\
\hline 11 & Entuyut & Nephentes sp & Nepenthaceae & Liana & Kejengkolan & Akar & Direbus & Diminum \\
\hline 12 & Gaharu & $\begin{array}{l}\text { Aquilaria } \\
\text { malaccensis Lam. }\end{array}$ & Thymelaeaceae & Pohon & Kolestrol & Daun & Direbus & Diminum \\
\hline 13 & Gamut & Myrmecodia sp & Rubiceae & Perdu & Penyakit gamut & Daun & Ditumbuk & Digosok \\
\hline 14 & GandaRusa & $\begin{array}{l}\text { Justicia gendarussa } \\
\text { Burm. f. }\end{array}$ & Acanthaceae & Perdu & Memar & Daun & Dipanaskan & Ditempel \\
\hline 15 & Gelinggang & Cassia alata $\mathrm{L}$. & Fabaceae & Perdu & $\begin{array}{l}\text { penyakit kulit } \\
\text { (panu) }\end{array}$ & Daun & Diremas & Digosok \\
\hline 16 & Ilalang & $\begin{array}{l}\text { Imperata cylindrica } \\
\text { (L.) Beauv. }\end{array}$ & Poaceae & Herba & $\begin{array}{l}\text { Penyakit } \\
\text { kuning }\end{array}$ & Akar & Direbus & Diminum \\
\hline 17 & Jahe antu & Zingiber $s p$ & Zingiberaceae & Herba & Bengkak & Buah & Ditumbuk & Ditempel \\
\hline 18 & Jeruk nipis & $\begin{array}{l}\text { Citrus aurantifolia } \\
\text { (Cristm.) Swingle }\end{array}$ & Rutaceae & Perdu & Batuk & Buah & Diperas & Diminum \\
\hline 19 & Kabu-kabu & Sterculia foetida $\mathrm{L}$. & Malvaceae & Pohon & Panas tinggi & Daun & Diremas & Ditempel \\
\hline 20 & Kedadai & $\begin{array}{l}\text { Ficus variegata } \\
\text { (Blume.) }\end{array}$ & Moraceae & Pohon & $\begin{array}{l}\text { Memperlancar } \\
\text { air susu }\end{array}$ & Daun & Direbus & Dimakan \\
\hline
\end{tabular}




\begin{tabular}{|c|c|c|c|c|c|c|c|c|}
\hline 21 & Kelapa & Cocos nucifera $\mathrm{L}$. & Arecaceae & Pohon & Gerumut & Buah & $\begin{array}{l}\text { Langsung } \\
\text { dipakai }\end{array}$ & Diminum \\
\hline 22 & Kelilik & & & Pohon & Bisul anak kecil & Buah & Dikunyah & Disembur \\
\hline 23 & $\begin{array}{l}\text { Kembang } \\
\text { sepatu }\end{array}$ & $\begin{array}{l}\text { Hibiscus } \\
\text { rosasinensis L. }\end{array}$ & Malvaceae & Perdu & Bisul & Daun & Ditumbuk & Ditempel \\
\hline 24 & Kemuntin & $\begin{array}{l}\text { Melastoma } \\
\text { malabathricum } \mathrm{L} \text {. }\end{array}$ & Melastomaceae & Perdu & Luka luar & Daun & Dikunyah & Ditempel \\
\hline 25 & Kereniyung & $\begin{array}{l}\text { Trema tomentosa } \\
\text { Var. Viridis }\end{array}$ & Cannabaceae & Perdu & Sakit anak & Daun & Diremas & Dioles \\
\hline 26 & $\begin{array}{l}\text { Kumis } \\
\text { Kucing }\end{array}$ & $\begin{array}{l}\text { Orthosiphon } \\
\text { aristatus }\end{array}$ & Lamiaceae & Perdu & Penyakit dalam & Daun & Direbus & Diminum \\
\hline 27 & Kunyit & $\begin{array}{l}\text { Curcuma domestica } \\
\text { Val. }\end{array}$ & Zingiberaceae & Herba & $\begin{array}{l}\text { Perawatan } \\
\text { pasca } \\
\text { melahirkan }\end{array}$ & Rimpang & Ditumbuk & Diminum \\
\hline 28 & Kunyit Putih & Curcuma zeodoaria & Zingiberaceae & Herba & Kanker & Rimpang & Direbus & Diminum \\
\hline 29 & Lengkuas & $\begin{array}{l}\text { Languas galanga L. } \\
\text { Wild }\end{array}$ & Zingiberaceae & Herba & Panu & Rimpang & Dibelah & Digosok \\
\hline 30 & Leyak & $\begin{array}{l}\text { Zingiber officinale } \\
\text { Roxb. var Rubra. }\end{array}$ & Zingiberaceae & Herba & $\begin{array}{l}\text { Menghangatkan } \\
\text { tubuh }\end{array}$ & Rimpang & Ditumbuk & Dimakan \\
\hline 31 & Lupun & $\begin{array}{l}\text { Poikilospermum } \\
\text { suaveolens (Blume) }\end{array}$ & Urticaceae & Pohon & Keputihan & Daun & Direbus & Diminum \\
\hline 32 & $\begin{array}{l}\text { Mahkota } \\
\text { Dewa }\end{array}$ & $\begin{array}{l}\text { Merr. } \\
\text { Phaleria } \\
\text { macrocarpa (Scheff) } \\
\text { Boerl. }\end{array}$ & Thymelaeaceae & Perdu & Penurun darah & Buah & Direbus & Diminum \\
\hline 33 & Mengkudu & Morinda citrifolia L. & Rubiceae & Pohon & Malaria & Daun & Direbus & Diminum \\
\hline 34 & Mentimun & Cucumis sativus L. & & Herba & Penurun darah & Buah & $\begin{array}{l}\text { Langsung } \\
\text { dipakai }\end{array}$ & Dimakan \\
\hline 35 & Pala & Cnestis palala & Connaraceae & Pohon & Sakit kepala & Daun & Direbus & $\begin{array}{l}\text { Untuk } \\
\text { mandi }\end{array}$ \\
\hline 36 & Pasak bumi & $\begin{array}{l}\text { Eurycoma longifolia } \\
\text { Jack }\end{array}$ & Simaroubaceae & Pohon & Demam & Akar & Direbus & Diminum \\
\hline 37 & Patah Kemudi & $\begin{array}{l}\text { Elephantopus scaber } \\
\text { L. }\end{array}$ & Asteraceae & Herba & Penyakit dalam & Daun & Ditumbuk & Diminum \\
\hline 38 & Pentabar & $\begin{array}{l}\text { Costus speciosus } \\
\text { Smith. }\end{array}$ & Costaceae & Perdu & $\begin{array}{l}\text { Susah } \\
\text { pencernaan } \\
\text { anak }\end{array}$ & Daun & Diremas & Dioles \\
\hline 39 & $\begin{array}{l}\text { Penyambung } \\
\text { Nyawa }\end{array}$ & $\begin{array}{l}\text { Amygdalinum } \\
\text { gymnanthemum } \\
\text { (Delile) Walp. }\end{array}$ & Asteraceae & Herba & Kolestrol & Daun & Direbus & Diminum \\
\hline 40 & Pepaya & Carica papaya L. & Caricaceae & Pohon & Malaria & Daun & Direbus & Diminum \\
\hline 41 & Rukam & $\begin{array}{l}\text { Flacourtia rukam } \\
\text { Zoll. \& Mor. }\end{array}$ & Flacourtiaceae & Pohon & $\begin{array}{l}\text { Penyakit BAB } \\
\text { berlendir }\end{array}$ & Daun & Direbus & Diminum \\
\hline 42 & $\begin{array}{l}\text { Sabang } \\
\text { Cucuk }\end{array}$ & Molineria sp & Hypoxidaceae & Herba & Sakit anak & Daun & Diremas & Digosok \\
\hline 43 & Sahang & Piper nigrum L. & Piperaceae & Liana & Perut kembung & Buah & Ditumbuk & Ditempel \\
\hline 44 & Samiroto & $\begin{array}{l}\text { Andrographis } \\
\text { paniculata (Burm. } \\
\text { f.) }\end{array}$ & Acanthaceae & Herba & Kolestrol & Daun & Direndam & Diminum \\
\hline 45 & Serai & $\begin{array}{l}\text { Cymbopogon ciratus } \\
\text { (DC.) Stapf }\end{array}$ & Poaceae & Semak & Batuk & Batang & Direbus & Diminum \\
\hline 46 & Sirih & Piper betle L. & Piperaceae & Liana & Sakit mata & Daun & Direbus & Ditetes \\
\hline
\end{tabular}


JURNAL HUTAN LESTARI (2019)

Vol. 7 (1) : 597 - 616

\begin{tabular}{|c|c|c|c|c|c|c|c|c|}
\hline 47 & Sirih merah & $\begin{array}{l}\text { Piper crotum Ruiz \& } \\
\text { Pav }\end{array}$ & Piperaceae & Liana & Keputihan & Daun & Direbus & Diminum \\
\hline 48 & Sirsak & Annona muricata $\mathrm{L}$. & Annonaceae & Pohon & Penurun darah & Daun & Direbus & Diminum \\
\hline 49 & Suluh Mata & $\begin{array}{l}\text { Schefflera } \\
\text { acutissima }\end{array}$ & Araliaceae & Pohon & Sakit mata & Daun & Direbus & Ditetes \\
\hline 50 & Tempelak & $\begin{array}{l}\text { Bauhinia tomentosa } \\
\text { L. }\end{array}$ & Fabaceae & Perdu & $\begin{array}{l}\text { Susah } \\
\text { pencernaan } \\
\text { anak }\end{array}$ & Daun & Diremas & Dioles \\
\hline 51 & Tepus Antu & Zingiber $s p$ & Zingiberaceae & Herba & Obat benik & Akar & Direbus & Diminum \\
\hline 52 & Ubi Kayu & $\begin{array}{l}\text { Manihot esculenta } \\
\text { Crantz. }\end{array}$ & Euphorbiaceae & Perdu & Maagh & Buah & Direbus & Dimakan \\
\hline
\end{tabular}

Hasil penelitian di lapangan dapat disimpulkan bahwa masih banyak masyarakat yang mempercayai penggunaan tumbuhan obat secara herbal, selain jenis tumbuhannya mudah didapatkan dan juga harganya masih relatif murah dibandingkan obat-obat modern. Terutama bagi para ibu-ibu yang menjalani proses persalinan dan paska melahirkan, selain itu juga seperti mengobati penyakit kolestrol, menurunkan darah, malaria dan ridap atau penyakit pencernaan yang kurang baik pada anak. Tumbuhan yang masih sering digunakan oleh masyarakat sekitar Hutan Adat Tawang Panyai di
Desa Tapang Semadak adalah 52 jenis tumbuhan. Pengenalan dan pemanfaatan jenis tumbuhan obat pada masingmasing daerah terdapat perbedaan jumlah jenis tumbuhan obat sehingga suatu jenis tumbuhan obat yang digunakan sebagai obat pada daerah tertentu belum tentu digunakan oleh kelompok lain pada daerah lain untuk mengatasi penyakit yang sama (Takoy et al. 2013).

Pemanfaatan Tumbuhan Obat

\section{Berdasarkan Nilai Guna}

Hasil pemanfaatan tumbuhan obat berdasarkan nilai guna dapat dilihat pada Gambar 7. 
JURNAL HUTAN LESTARI (2019)

Vol. 7 (1) : 597 - 616

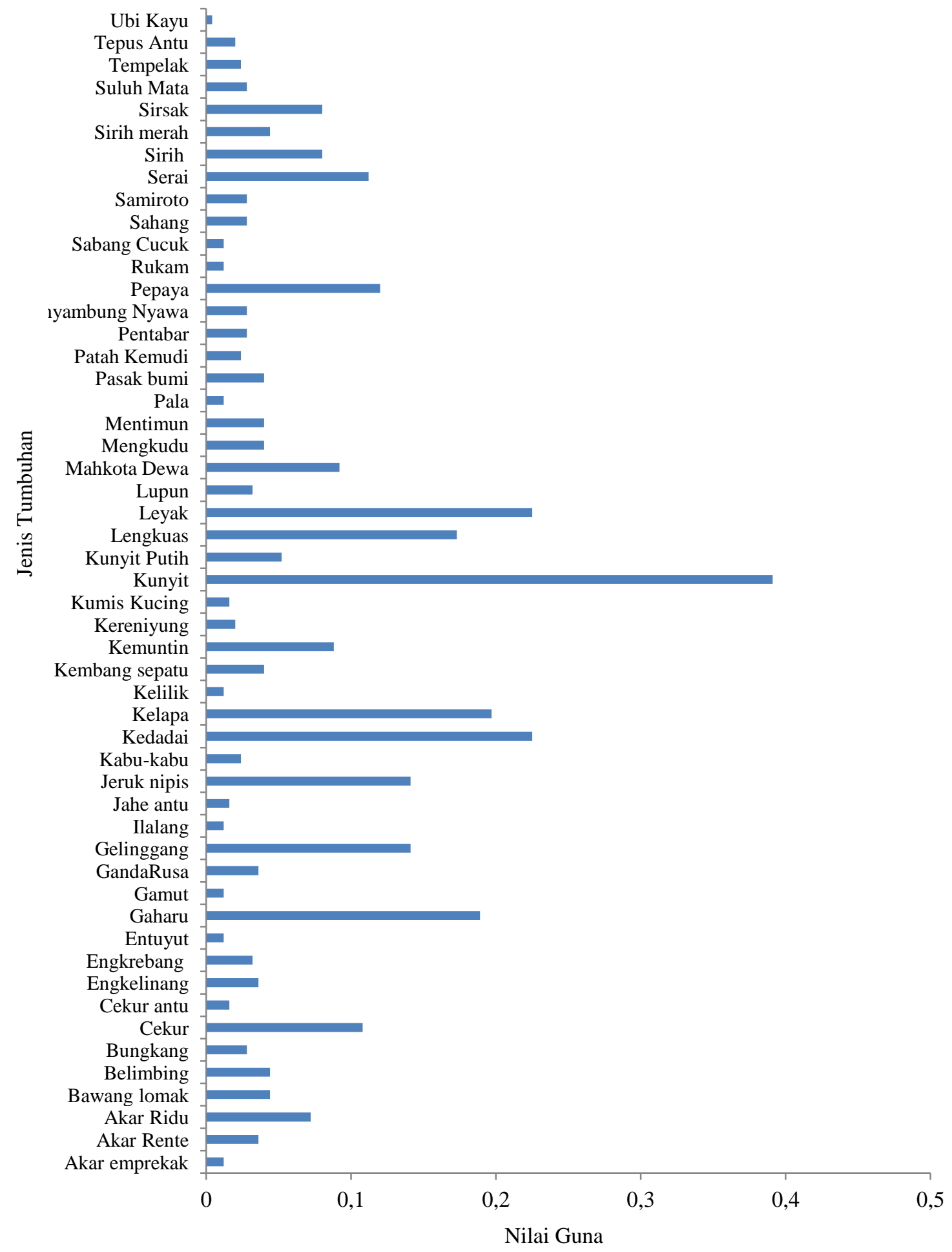

Gambar 7. Jenis Tumbuhan Obat Berdasarkan Nilai Guna (Species of Medicinal Plants Based on Use Value)

Nilai guna jenis tumbuhan obat domestica Val.) sebesar 0,391 yang tertinggi terdapat pada kunyit $(C$ sedangkan nilai guna terendah terdapat 
pada ubi kayu (Manihot esculenta Crantz.) sebesar 0,004. Menurut Albuquerque et al. (2006) jenis tumbuhan dengan nilai Uvs tinggi menunjukkan bahwa jenis tumbuhan tersebut memilikibanyak manfaat dan tingkat pengetahuan bersama tentang manfaat tumbuhan tersebut di masyarakat. Hasil perhitungan nilai guna jenis didapati 10 jenis tumbuhan dengan nilai UVs tertinggi. Kesepuluh tanaman dengan nilai Uvs tertinggi adalah kunyit (C. domestica Val.), kedadai ( $F$. variegata Blume.), leyak ( $Z$. officinale Roxb. var Rubra.), kelapa ( $C$. nucifera L.), gaharu (A. malaccensis Lam.), lengkuas (A. galanga L. Wild), gelinggang (Cassia alata L.), jeruk nipis (C. aurantifolia (Cristm.) Swingle), pepaya (C. papaya L.) dan serai (C. ciratus (DC.) Stapf).

Kunyit (C. domestica Val.) tanaman ini sangat dipercaya oleh masyarakat di Desa Tapang Semadak sebagai obat. Sebanyak 97 wanita yang menggunakan tanaman ini karena dipercaya membatu perawatan paska melahirkan dimana kunyit dapat membersihkan luka-luka didalam tubuh. Pengolahan kunyit ini sangat mudah dilakukan yaitu cuci bersih rimpang kunyit kemudian tumbuk atau blender sampai halus stetelah itu masukkan air hangat kuku dan langsung diminum. Berdasarkan penelitian Setyowati et al. (2005) bahwa masyarakat Dayak Ngaju di Daerah Timpah Kalimantan Tengah mengenal tentang perawatan untuk ibuibu setelah mengalami proses persalinan di antaranya untuk membersihkan sisasisa darah kotor mereka meminum air parutan dari buah mengkudu ( $M$. Citrifolia).

\section{Pemanfaatan Tumbuhan Obat berdasarkan Famili}

Hasil pemanfaatan tumbuhan obat berdasarkan famili dapat dilihat pada Gambar 8. 
JURNAL HUTAN LESTARI (2019)

Vol. 7 (1) : 597 - 616

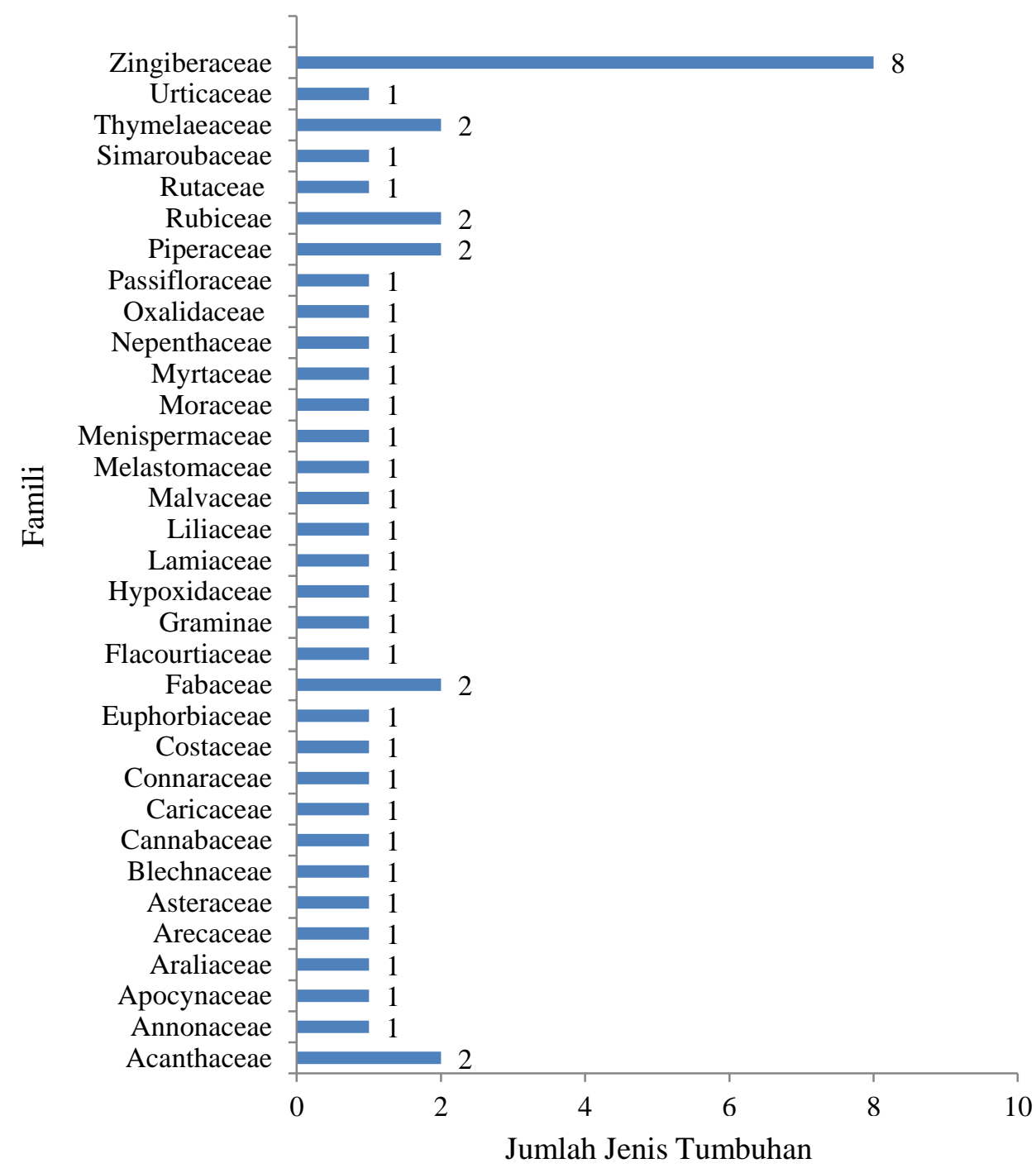

Gambar 8. Jumlah Jenis Tumbuhan Obat Berdasarkan Famili (Species of Medicinal Plants Based on Family)

Famili Zingiberaceae menempati jumlah terbanyak yang ditemukan pada penelitian ini yaitu 8 jenis tumbuhan. Jenis tumbuhan yang masuk kedalam famili Zingiberaceae tersebut adalah cekur (K. galanga), cekur antu (Kaempferia sp), jahe antu (Zingiber $s p$ ), kunyit ( $C$. domestica), kunyit putih (C. zeodoaria), lengkuas (A. galanga $\mathrm{L}$. Wild), leyak (Z. officinale), dan tepus antu (Zingiber $s p$ ). Bagian yang dimanfaatkan dari famili zingiberaceae adalah bagian rimpang kecuali cekur antu, jahe antu dan tepus antu yang dimanfaatkan adalah daun dan akar.

Famili Zingiberaceae secara umum dikenal oleh masyarakat Indoneasia sebagai tumbuhan jahe-jahean yang dimanfaatkan sebagai obat tradisional (Takoy et al. 2017). Hasil yang sama juga ditemukan pada etnis sakai di Desa Petani Kecamatan Mandau Kabupaten 
Bengkalis Duri, Riau yang menggunakan 98 spesies dan 48 famili tumbuhan obat dengan famili tertinggi digunakan adalah Zingiberaceae. Zingiberaceae pada umumnya merupakan kelompok jahe-jahean dengan ciri-ciri perawakan herba, memiliki rimpang dibawah permukaan tanah, batang semu, tipe daun lengkap dan daun tunggal (Wulandari et al. 2014).

Pemanfaatan Tumbuhan Obat Berdasrkan Habitus

Berdasarkan hasil di lapangan tumbuhan obat berdasarkan habitus dapat dilihat pada Gambar 9.

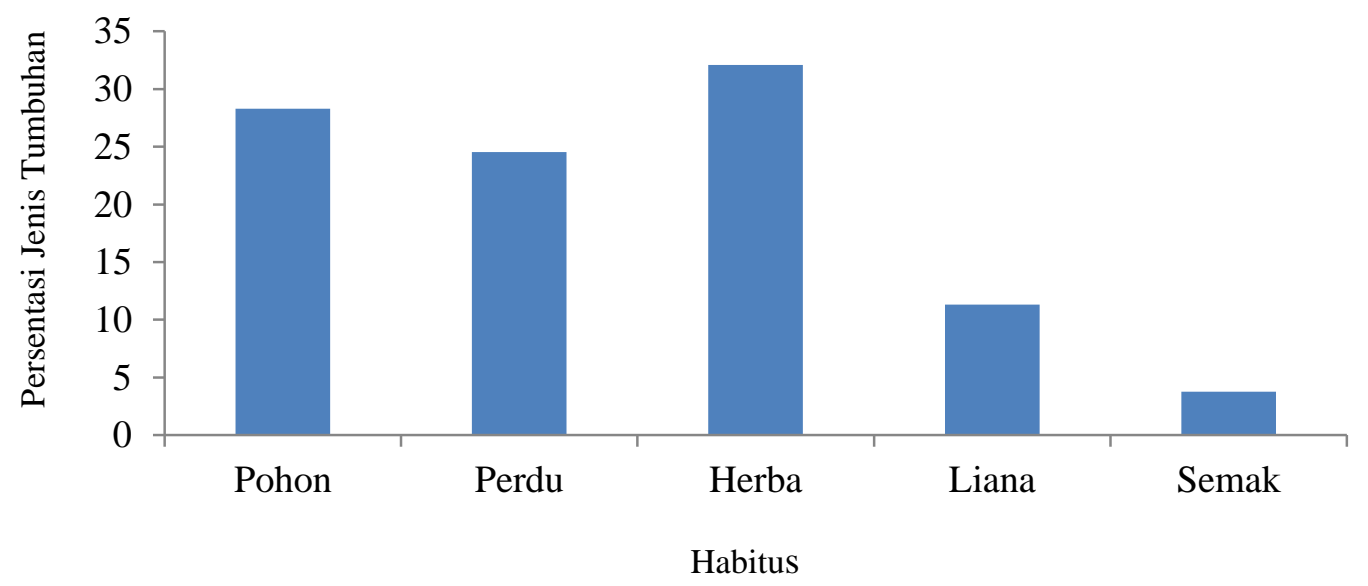

Gambar 9. Persentase Tumbuhan Obat berdasarkan habitus (Percentage of Medicinal Plants Based on Habitus)

Tingkat habitus tumbuhan obat yang paling banyak digunakan adalah tingkat herba yaitu 17 jenis dengan persentase $32,08 \%$ sedangkan yang paling sedikit adalah tingkat semak yaitu 15 jenis dengan persentase $28,30 \%$. Hasil pengamatan di lapangan, diperoleh jenis tumbuhan obat yang digunakan oleh masyarakat umumnya adalah jenis yang berupa tumbuhan bawah dan juga beberapa jenis yang merupakan tumbuhan kayu. Hasil yang sama didapatkan pada penelitian di Kawasan IUUPHK PT. Sari Bumi Kusuma Camp Tontang Kabupaten dimana masyarakat lebih banyak menggunakan tumbuhan obat berupa tumbuhan bawah (Deden et al. 2012). Tumbuhan bawah adalah komunitas tanaman yang menyusun stratifikasi bawah dekat permukaan tanah. Tumbuhan ini umumnya berupa rumput, herba, semak, atau perdu renda (Suharti, 2015).

\section{Pemanfaatan Tumbuhan Obat}

\section{Berdasarkan Bagian Yang}

Digunakan

Bagian tumbuhan obat yang dimanfaatkan sebagai bahan baku obat berupa daun, akar, buah, rimpang, batang dan biji. Persentasi jenis tumbuhan obat berdasarkan bagian yang digunakan dapat dilihat pada Gambar 10. 


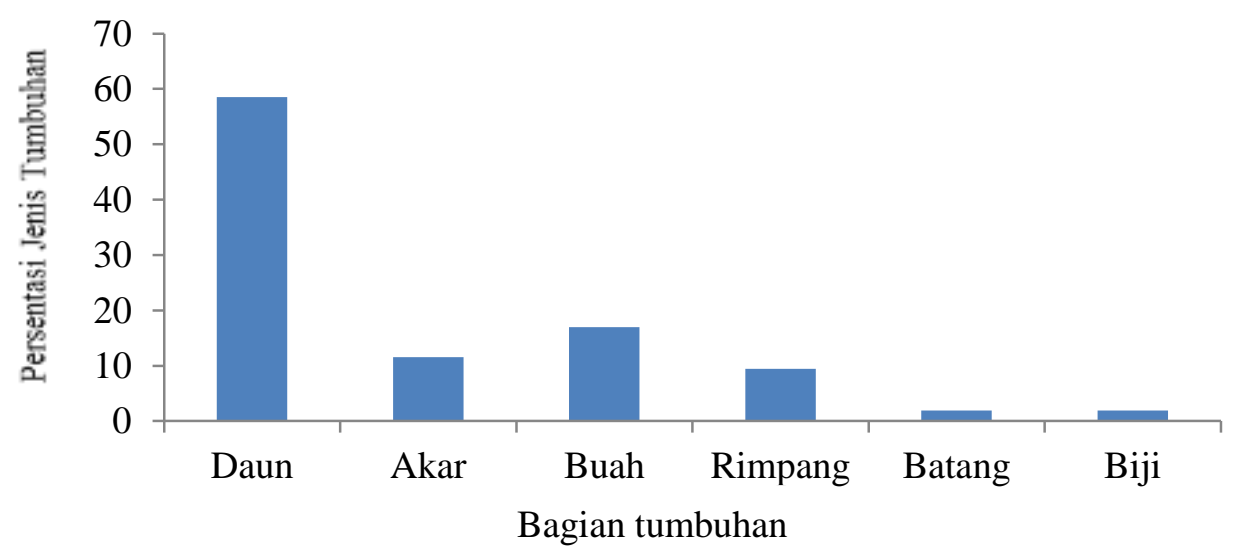

Gambar 10. Persentase Berdasarkan Bagian yang Digunakan (Percentage Based on Parts Used)

Berdasarkan bagian tumbuhan obat yang dimanfaatkan masyarakat diketahui bahwa bagian yang banyak digunakan adalah daun yaitu 31 jenis dengan persentase $58,49 \%$ dan yang paling sedikit adalah batang dan biji yaitu 1 jenis dengan persentase $1,89 \%$. Seperti penelitian yang lainnya tentang tumbuhan obat pada suatu masyarakat pada umumnya daun merupakan bagian tumbuhan yang paling banyak digunakan. Hasil penelitian serupa juga ditemukan pada masyarakat suku Dayak Iban Desa Sungai Mawang Kalimantan Barat dimana bagian daun merupakan bagian tumbuhan yang paling banyak digunakan sebagai tumbuhan obat (Pradityo et all. 2017). Masyarakat suku Dayak Jangkang Tanjung di Desa Ribau Kecamatan Kapuas Kabupaten Sanggau juga menunjukkan bahwa bagian tumbuhan yang paling banyak digunakan adalah daun (Sari et all.
2015). Masyarakat suku Dayak Kerabat di Desa Tapang Perodah Kecamatan Sekadau Hulu Kabupaten Sekadau juga menunjukkan bahwa daun merupakan bagian tumbuhan yang paling banyak digunakan (Kuni et al. 2015). Hal ini menunjukkan bahwa pemanfaatan tumbuhan oleh masyarakat dilakukan secara lestari., karena pada umumnya pengambilan bagian tumbuhan tersebut tidak memberikan dampak yang besar pada tumbuhan tersebut.

Pemanfaatan Tumbuhan Obat Berdasarkan Jenis Penyakit Yang Diobati

Pengobatan dengan menggunakan tumbuhan obat oleh masyarakat Desa Tapang Semadak dapat diklasifikasikan menjadi 2 macam, penyakit luar dan penyakit dalam. Berikut ini merupakan persentase jenis penyakit yang diobati dengan tumbuhan obat dapat dilihat pada Gambar 11. 


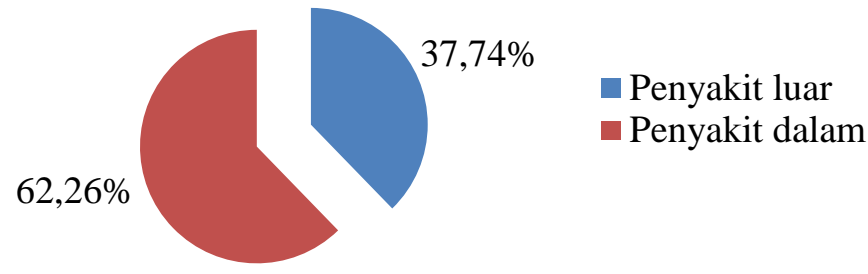

Gambar 11. Persentase Berdasarkan Penyakit Yang Diobati (Percentage Based on Treated Disease)

Masyarakat di Desa Tapang Semadak memanfaatkan tumbuhan obat dengan berbagai jenis penyakit dan tumbuhan yang digunakan. Berdasarkan hasil wawancara dan hasil dilapangan penyakit yang sering disembuhkan dengan memanfaatkan tumbuhan obat adalah perawatan ibu-ibu paska melahirkan, memperlancar ASI, menghangatkan tubuh, gerumut, kolestrol, panu, batuk, dan malaria. Penyakit dalam merupakan jenis penyakit yang banyak disembuhkan dalam pemanfaatan tumbuhan obat oleh masyarakat Desa Tapang Semadak yaitu 32 jenis dengan persentase $62,26 \%$. Jenis penyakit dalam yang diobati dikelompokkan menjadi 19 kelompok yaitu, rematik, malaria, kolestrol, penurun darah, ridap (penyakit pada anak seperti sakit BAB pada anak),

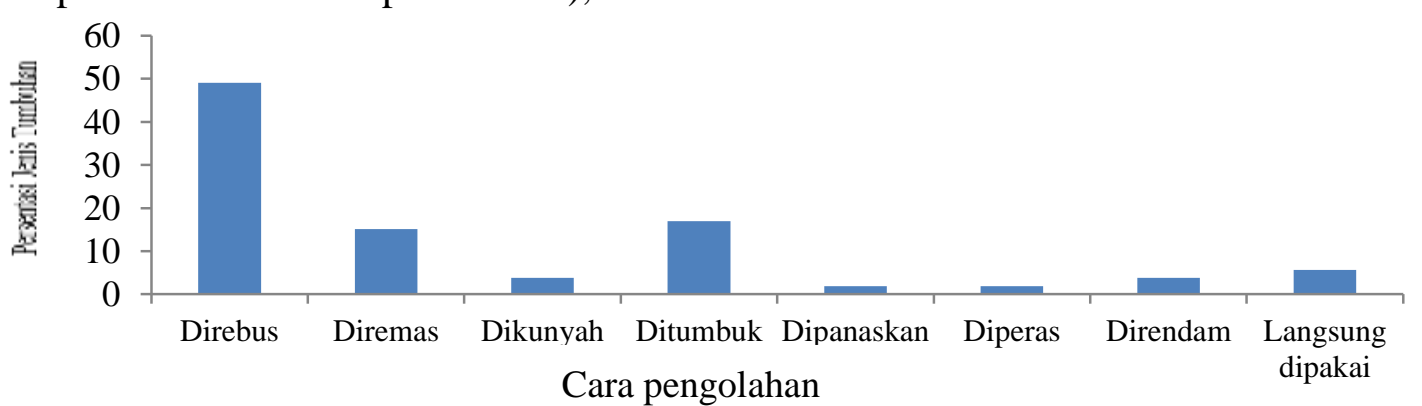

Gambar 12. Persentase Berdasarkan Cara Pengolahan (Percentage Based on Processing Method) kejengkolan, penyakit kuning, batuk, memperlancar ASI, gerumut, penyakit dalam, perawatan paska melahirkan, kanker, menghangatkan tubuh, keputihan, demam, penyakit $\mathrm{BAB}$ berlendir, sakit dan maagh.

\section{Pemanfaatan Tumbuhan Obat} Berdasarkan Cara Pengolahan

Berdasarkan hasil penelitian tumbuhan obat yang dimanfaatkan masyarakat di Desa Tapang Semadak Kecamatan Sekadau Hilir Kabupaten Sekadau masyarakat mengolah tumbuhan sangat beragam diantaranya dengan cara direbus, diremas, dikunyah, ditumbuk, dipanaskan, diperas, direndam, dibelah dan langsung dipakai. Persentasi tumbuhan obat berdasarkan cara pengolahan dapat dilihat pada Gambar 12. Cara pengolahan 
Cara pegolahan tumbuhan obat yang paling banyak digunakan oleh masyarakat Desa Tapang Semadak adalah dengan cara direbus yaitu 27 spesies dengan persentase $49,06 \%$ sedangkan yang paling sedikit adalah pengolahan dengan cara dipanaskan dan diperas yaitu 1 spesies dengan persentase $1,89 \%$. Penelitian pada masyarakat Suku Dayak Jangkang Tanjung di Desa Ribau Kecamatan Kapuas Kabupaten Sanggau juga menunjukkan bahwa pengolahan tumbuhan obat yang paling banyak digunakan adalah dengan cara direbus. Hal ini dipercaya oleh masyarakat tersebut sebagai metode pengolahan yang akan mengeluarkan lebih banyak kandungan kimia dibandingkan dengan cara yang lainnya (Sari et al. 2015).
Masyarakat di Desa Tapang Semadak pengolahan tumbuhan obat paling banyak digunakan dengan cara direbus karena penyakit yang sering mereka rasakan merupakan penyakit dalam dan dengan cara meminum ramuan tersebut dengan cepat merasakan reaksi yang akan lebih cepat merasakan lebih sembuh.

\section{Pemanfaatan Tumbuhan Obat Berdasarkan Cara Penggunaannya}

Berdasarkan cara penggunaan tumbuhan obat dari 52 jenis dalam pemanfaatannya masyarakat sangat beragam diantaranya diminum, disembur, ditempel, digosokk, dioles, ditetes, dimakan, dan untuk mandi. Persentasi tumbuhan obat berdasarkan cara penggunaannya dapat dilihat pada Gambar 13.

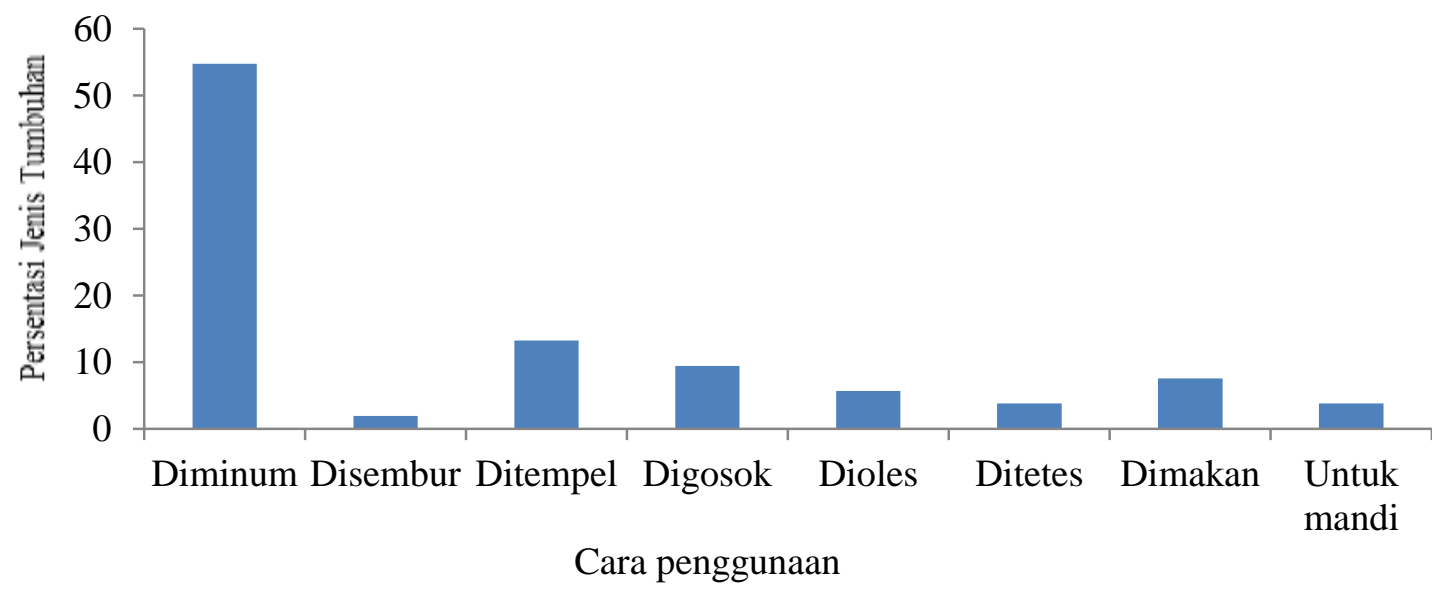

Gambar 13. Persentase berdasarkan Cara Penggunaannya (Percentages based on how they are used)

Cara penggunaan yang banyak digunakan adalah dengan cara diminum yaitu 29 jenis dengan persentase $54,72 \%$ dan yang sedikit dengan cara disembur yaitu 1 jenis dengan persentase $1,89 \%$. Penelitian pada etnis dayak di Desa Gerantung Kecamatan Monterado Kabupaten Bengkayang juga menunjukkan bahwa masyarakat paling banyak memanfaatkan tumbuhan obat dengan cara diminum (Gunadi et al. 2017). 
Pengobatan yang banyak digunakan dengan cara diminum karena cara ini paling mudah dan cepat dalam penyembuhan seperti tumbuhan jeruk nipis (Citrus aurantifolia) cara penggunaannya yaitu peras 3-5 buah jeruk nipis tambahkan sedikit garam kedalamnya langsung diminum, air perasan tersebut mampu meredakan dan melegakan tenggorokan saat sedang batuk. Hal ini dikarenakan masyarakat setempat meyakini bahwa dengan cara

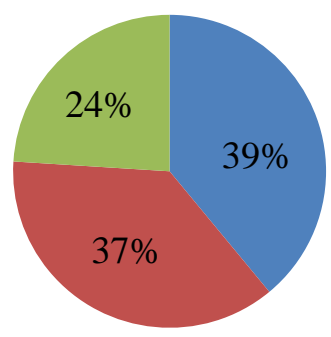

diminum akan lebih cepat reaksinya dibandingkan dengan cara dibalur (Gunadi et al. 2017).

Lokasi Pengambilan Tumbuhan Obat Berdasarkan hasil penelitian mbuhan obat yang digunakan oleh tmasyarakat di Desa Tapang Semadak ditemukan di Hutan Adat Tawang Panyai, perkarangan rumah dan ladang. Lokasi pengambilan tumbuhan obat dapat dilihat pada Gambar 8.

Hutan Adat Tawang

Panyai

- Perkarangan Rumah

Ladang

Gambar 8. Lokasi Pengambilan Tumbuhan Obat (Location for taking medicinal plants) 
Tumbuhan obat yang dimanfaatkan oleh masyarakat umumnya langsung diambil dari hutan, pekarangan rumah dan ada yang dibudidayakan masyarakat. Berdasarkan hasil penelitian tumbuhan yang banyak ditemukan adalah di Hutan Adat Tawang Panyai dan perkarangan rumah, hal ini sama seperti penelitian Meliki et al. (2013) di Desa Tanjung Sari Kecamatan Ketungau Tengah Kabupaten Sintang yaitu lokasi pengambilan tumbuhan obat oleh Suku Dayak Iban paling banyak dari hutan. Banyaknya pengambilan di hutan disebabkan karena keanekaragaman jenis tumbuhan berkhasiat obat di hutan masih cukup tinggi dan luasnya kawasan hutan. Masyarakat Desa Tapang Semadak memanfaatkan tumbuhan obat berdasarkan pengetahuan yang diwariskan orang tuanya secara turun-temurun seperti bentuk ramuan, bagian yang digunakan, cara pegolahan, cara penggunaan dan penyakit yang diobati. Pengambilan tumbuhan obat dari hutan tidak terlalu sering dilakukan karena untuk mengobati penyakit yang umum diderita masyarakat hanya memanfaatkan spesies tumbuhan obat yang ada di lingkungan sekitar. Pengambilan spesies tumbuhan obat dari hutan hanya dilakukan oleh orang-orang yang akan mengobati penyakit yang cukup berat.

\section{Kesimpulan}

1. Hasil penelitian di Desa Tapang Semadak Kecamatan Sekadau Hilir Kabupaten Sekadau terhadap 248 responden diperoleh :

$\begin{array}{llr}\text { Responden } & \text { yang banyak } \\ \text { menggunakan } & \text { tumbuhan } \quad \text { obat }\end{array}$

adalah perempuan. Sebagian besar responden bekerja sebagai petani hal ini dikarenakan pendidikan masyarakat yaang masih sangat rendah sehingga mayoritas memilih untuk berkebun dan berladang. Responden juga tergolong dalam umur dewasa dan lansia dikarenakan semakin bertambahnya usia serta anggota keluarga maka pengetahuan yang diperoleh akan semakin bertambah. Mayoritas agama masyarakat yaitu katolik dengan suku dayak De'sa.

2. Hasil penelitian dilapangan ditemukan 52 jenis tumbuhan obat yang dikelompokkan kedalam 33 famili. Jenis famili yang banyak digunakan masyarakat adalah zingiberaceae, berdasarkan tingkat habitus yang paling banyak digunakan adalah tingkat herba yaitu 17 jenis $(32,08 \%)$, berdasarkan bentuk ramuan yang banyak digunakan adalah bentuk ramuan tunggal yaitu 49 jenis (92\%), berdasarkan bagian tumbuhan obat yang banyak digunakan adalah daun yaitu 31 jenis $(58,49)$, berdasarkan cara pegolahan tumbuhan obat yang paling banyak digunakan adalah dengan cara direbus yaitu 27 spesies (49,06\%), berdasarkan cara penggunaan yang banyak digunakan adalah dengan cara diminum yaitu 29 jenis $(54,72 \%)$, berdasarkan jenis penyakit yang banyak digunakan adalah penyakit dalam yaitu 32 jenis $(62,26)$, berdasarkan tumbuhan yang banyak ditemukan adalah di Hutan Adat Tawang Panyai dan perkarangan rumah. 


\section{Saran}

1. Masyarakat Desa Tapang Semadak Kecamatan Sekadau Hilir Kabupaten Sekadau perlu membudidayakan tumbuhan obat yang ada pada kawasan Hutan Adat Tawang Panyai.

2. Perlu adanya perlindungan terhadap tumbuhan obat serta pembinaan secara terpadu dengan penyuluhan yang berkelanjutan agar masyarakat dapat mengetahui dan memahami akan pentingnya kelestarian dan pemanfaatan tumbuhan obat.

\section{DAFTAR PUSTAKA}

Due R, Swisna S, Marlina R. 2014. Etnobotani Tumbuhan Obat Suku Dayak Pesaguan dan Implementasinya dalam Pembuatan Flash Card Biodiversitas. Jurnal Pendidikan dan Pembelajaran 2(3).

Gunadi D, Oramahi HA, Tavita GE. 2017. Studi Tumbuhan Obat Pada Etnis Dayak di Desa Gerantung Kecamatan Monterado Kabupaten Bengkayang. Jurnal Hutan Lestari $5(2): 425-436$.

Hamzari. 2008. Identifikasi Tanaman Obat Obatan yang dimanfaatkan oleh Masyarakat Sekitar Hutan Tabo-Tabo. Jurnal Hutan dan Masyarakat 3(2) : 111-234.

Hidayat D, Hardiansyah G. 2012. Studi Keanekaragaman Jenis Tumbuhan Obat di Kawasan IUPHHK PT. Sari Bumi Kusuma Camp Tontang Kabupaten Sintang. Vokasi 8 (2) : 61-68.

Hoffman B dan Gallaher T. 2007. Importance Indices in Ethnobotany. Ethnobotany Research \& Aplication 5 : 201218.
Kumalasari. 2006. Pemanfaatan Obat Tradisional dengan Pertimbangan Manfaat dan Keamanan. Universitas Indonesia. Depok. Artikel Majalah Ilmu Kafarmasian 3(1) : 1-7.

Kuni B E, Hardiansyah G, Idham M. 2015. Etnobotani Masyarakat Suku Dayak Kerabat Di Desa Tapang Perodah Kecamatan Sekadau Hulu Kabupaten Sekadau. Jurnal Hutan Lestari $3(3)$ : 383-400.

Pradityo T, Santoso N, Zuhud EAM. 2016. Etnobotani di Kebun Tembawang Suku Dayak Iban Desa Sungai Mawang Kalimantan Barat. Media Konservasi 21(2) : 183-198.

Sari A, Linda R, Lovadi I. 2015. Pemanfaatan Tumbuhan Obat Pada Masyarakat Suku Dayak Jangkang Tanjung Di Desa Ribau Kecamatan Kapuas Kabupaten Sanggau. Protobiont. 4(2) : 1-8.

Suharti S. 2015. Pemanfaatan Tumbuhan Bawah di Zona Pemanfaatan Taman Nasional Gunung Merapi oleh Masyarakat sekitar Hutan. Pros Sem Nas Masy Biodiv Indon 6(1) : 14111415.

Takoy DM, Linda R, Lovadi I. 2013.Tumbuhan Berkhasiat Obat Sukun Dayak Seberuang di Kawasan Hutan Desa Ensabang Kecamatan Sepauk Kabupaten Sintang. Jurnal Protobiont 2(3) : 122-128.

Wulandari, Fitmawati, Sofiyandi N. 2014. Eksplorasi Pengetahuan Tumbuhan Obat Etnis Sakai di Desa Petani, Duri-Riau. JOM FMIPA 2 